\title{
Review Effect of Combined Application of Organic and Inorganic Fertilizer on Cabbage and Its Economic Importance's
}

\author{
Adane Fentaye Belay \\ Department of Horticulture, Wolkite University, Ethiopia
}

\begin{abstract}
Cabbage belongs to the family cruciferae. Among the other vegetable cabbage is one of the easiest crops to establish and most of the people grow this crop in their home garden. In the major vegetable-growing areas, it is also an essential economical and rotational crop. Cabbage is an important vegetable crop and it is one of favorite crop grown in kitchen garden because easy to rise. Cabbage is high in vitamins $\mathrm{A}, \mathrm{C}, \mathrm{K}, \mathrm{B}_{1}, \mathrm{~B}_{2}, \mathrm{~B}_{6}$, calcium, dietary fiber, and protein whether eaten fresh in salads or boiled or cooked in stews and soups. Cabbage is commonly consumed as a cooked or stir-fried vegetable, or as a raw element in salads such as coleslaw and mixed salads. Cabbage growth and yield are known to be influenced by a variety of cultural practices and growing settings. Nutrition is a major determinant of cabbage growth and production. Production of cabbage could be enhanced through efficient use of applied both organic and inorganic fertilizer. When compared to chemical fertilizers, organic fertilizers (cow dung, poultry manure, and vermin-compost) resulted in better nutrient uptake. Due to decreasing soil fertility, vegetable crop yields decreased. Organic manure can help to keep soil fertility and crop production in check. It is true that the use of inorganic fertilizers for crops has a negative impact on soil health, but organic fertilizers do not have this issue. Neither chemical fertilizers nor organic manure can help achieve long-term crop yield on their own. Because of deterioration in soil physical, chemical, and biological qualities, high yield levels could not be sustained using simply balanced chemical fertilizers over time. Integrated nutrient management is the most effective method for ensuring long-term soil fertility and productivity of cabbage. The objective of this review is to review the effect of combined application of organic and inorganic fertilizer on cabbage and its economic importance's.
\end{abstract}

Keywords: cabbage, organic, inorganic, combined, fertilizer

DOI: $10.7176 / \mathrm{JBAH} / 11-19-02$

Publication date:October $31^{\text {st }} 2021$

\section{INTRODUCTION}

Cabbage (Brassica oleracea var. capitata L.) a biennial crop with a short stem holding a mass of overlapping leaves from a var. capitata, belongs to the cruciferae family. It came from wild nonheaded type 'colewarts' (crambecordifolias) from Western Europe and the Mediterranean's northern shore (Semuli, 2005). Cabbage grows well in a wide range of climates, including temperate and tropical, although it thrives best in a cool, damp climate (Kibar et al., 2014). Cabbage takes 60 to 100 days from sowing to market maturity, depending on the cultivar. It's best to use a well-drained sandy loam soil with good organic content and a $\mathrm{pH}$ of 6.0 to 6.5. (Yano et al., 1999). Cabbage is an excellent source of nitrogen and potassium. For head cabbage, higher amounts of nitrogen and potassium should be applied than phosphorus when soils are infertile (Sorensen, 2003).

Ethiopia has the highest livestock Resource in Africa. The traditional balance between people, livestock and their habitat and the socio-economic systems is fast disappearing. As a result, achieving long-term increases in agricultural production has been a top priority for the country (Wakene et al., 2001). Most smallholder farmers in tropical Africa, such as Ethiopia, use inorganic fertilizers insufficiently due to the unavailability and high cost of chemical fertilizers. In Ethiopia, most smallholder farmers use inorganic fertilizers at lower rates than recommended for crop production (Bumb and Baanate, 1996). Organic fertilizers, on the other hand, remain a primary source of mineral elements, particularly among resource-scarce farmers in underdeveloped nations. However, the utilization of organic fertilizers such as farm yard manure for crop productivity is highly dependent on the farming system in place.

Farmyard manure could become a major nutrient source for crops in areas where crop and livestock production are somewhat integrated, reducing the demand for costly artificial fertilizers. Furthermore, nutrients in organic manures are released more slowly and are kept in the soil for a longer period of time, resulting in a longer residual effect that supports stronger root development and higher crop yields (Bhuiyan, 2010). However, it has been noted that using organic fertilizers alone to sustain cropping is insufficient due to a lack of availability in sufficient amounts and their relatively low nutrient content (Palm et al., 1997). Some aspects must be considered in order to sustain and improve cabbage output through agronomic measures. For optimal vegetable production, integrated nutrient management and correct agricultural methods such as optimum nutrient administration must be followed (Bulluck et al., 2002).

As a result, combining organic and inorganic fertilizer sources can improve soil health and optimize cabbage output, and because it uses local resources, it is thought to be a sensible, realistic, and economically 
viable method of giving nutrients to the crop. For head cabbage production, MoARD (2011) recommended using $235 \mathrm{~kg} \mathrm{ha}^{-1} \mathrm{~N}$ and $110 \mathrm{~kg} \mathrm{ha}^{-1} \mathrm{P}$, according to the crop variety registry bulletin. Organic manures are also an essential supply of plant vitamins however comprise incredibly in small amounts, which aren't with ease to be had. On the opposite hand, inorganic fertilizer includes specific, higher, and with ease to be had plant vitamins. So the aggregate of natural manures and inorganic fertilizers is in all likelihood to be greater productive. Cabbage is a heavy feeder and calls for supplemental fertilizer within side the shape of manure or compost and inorganic fertilizers. The utility prices of fertilizers have to be decided primarily based totally at the fertility popularity of the soil (Bok et al., 2006).

\section{OBJECTIVE OF THE STUDY}

To review the effect of combined application of organic and inorganic fertilizer on cabbage and its economic importance's.

\section{LITERATURE REVIEW}

\subsection{Origin and Distribution of Cabbage}

Cabbage (Brassica oleracea var. capitata L.) is a popular Cole crop that belongs to the Cruciferae or Brassicaceae family. It is native to Western Europe and the Mediterranean Region's Northern Shore (Singh et al., 2015). Cabbage was developed from the wild, leafy, non-heading forms of Brassica oleracea var. sylvestris (Moamogwe, 2005). Cabbage is one of the oldest vegetables, having been produced for over 4,000 years (Schlegel, 2010). It was the first Cole crop to be farmed by humans, and Romans loved it (Anonymous, 2011).

Cabbage is grown in more than 90 countries around the world for its head (Meena et al., 2010). China, India, South Korea, Germany, Japan, and South Africa are the world's leading cabbage producers (Sarker, 2002). Cabbage is the world's fifth most popular vegetable crop. In 2011, the global area planted with headed cabbage was predicted to be around 68.584 million hectare (FAO, 2008). According to FAOSTAT (2013-14), the total area grown under Cabbages in the world is approximately 2,416,885 hectares, with a total production of approximately 70,644,191 metric tons and an average productivity of approximately $29.23 \mathrm{MT} / \mathrm{ha}$. China and India accounted for nearly $60 \%$ of global cabbage production, with 46.4 percent and 12.8 percent, respectively. With 71.2 and 67.6t ha ${ }^{-1}$, respectively, the Republic of Korea and Japan are the world leaders in cabbage productivity (FAOSTAT, 2013-14; IHD, 2014). Cabbage is one of the most common vegetables farmed in South Africa, according to the National Department of Agriculture (2003).

Kenya, Egypt, Ethiopia, Niger, and South Africa are the top five cabbage growers in Africa, and they have maintained their supremacy in the field throughout this time. Ethiopia accounted for $12 \%$ of Africa's total production (Nicolas et al., 2012). Cabbage is grown on 38,000 hectares of land in Ethiopia; with a mean average yield of 395,000 tons using irrigation and rain feed. In comparison to the world average, Ethiopia's cabbage productivity is very low (10.4 $\left.\mathrm{t} \mathrm{ha}^{-1}\right)$ (FAOSTAT, 2013-14). Cabbage production has a lot of promise in the Amhara region. In 2013, the region generated more than $20.00 \mathrm{mt}$. The global average output is $10-40$ tons per hectare (Ogbodo, 2009).

Cabbage is tolerant of a wide range of environmental conditions. Cabbage, on the other hand, thrives in cool, damp conditions at altitudes between 500 and 1700 meters above sea level (Copenhagen market) and 5001700 meters above sea level (Early drum head) (Molla Tefera, 2009). The ideal temperature range for cabbage growth and head formation is $15-20^{\circ} \mathrm{C}$. The average relative humidity should be between 60 and 90 percent (FAO, 2012). When the temperature climbs above $25^{\circ} \mathrm{C}$, most cabbage varieties stop growing (Chadha, 2006). Cabbage grows best at temperatures between 15 and 20 degrees Celsius. When the temperature climbs above $30^{\circ} \mathrm{C}$, most cabbage varieties stop growing (Chadha, 2006).

However, if the temperature rises beyond $270^{\circ} \mathrm{F}$, it may bolt, causing the heads to break open (Ashworth, 2002). With heads weighing between 2 and $2.5 \mathrm{~kg}$, the best yields are attained during the cool and dry season. The average weight of a head during the hot rainy season is between 1 and 1.5 kilograms (Romain, 2001).

Cabbage cultivated for early market should have a strong rate of growth and be harvested as soon as it reaches a size that fulfills the needs of the consumer. Cabbage heads used for processing are larger than those used for storage or fresh market, weighing 5 to $8 \mathrm{~kg}$ and measuring 20 to $40 \mathrm{~cm}$ in diameter (Illert 2005). They are commonly harvested mechanically, however smaller heads weighing less than $2-3 \mathrm{~kg}$ for lengthy storage are recommended to be harvested manually (Illert 2005). For several European and American fresh markets, the demand for head weights of $1-2 \mathrm{~kg}$ is the emerging trend. Reduced head size can be achieved primarily through high density planting, cultivar selection, and the employment of other parameters such as cultivation method, water delivery rate, and fertilizer level (Illert 2005). Cabbage growth and yield are known to be influenced by a variety of cultural practices, nutrition and growing settings. Cabbage production could be improved by making better use of applied nitrogen and using measures that promote effective and efficient use of applied water, as ensured by drip irrigation technology (Asare et al., 2010). For cabbage, total nitrogen fertilizer levels of 160 to $260 \mathrm{~kg} \mathrm{ha}^{-1}$ are recommended (The Fertilizer Society of South Africa, 2000). 


\subsection{Economic Importance of Cabbage}

Among the other vegetable crops, cabbage is one of the simplest to grow, and the majority of people grow it in their backyard gardens. In the major vegetable-growing areas, it is also an essential economical and rotational crop (Ali stribigge and Andresen, 2013). Cabbage is often used as a vegetable. It's also used in salads with tomato, green chiles, beetroot, and other vegetables. It is high in sulfur and contains amino acids, minerals, carotenes, ascorbic acid, and antioxidants, as well as being anti-carcinogenic (Singh et al., 2009). Cabbage is often used in traditional medicine to treat symptoms related with gastrointestinal diseases (gastritis, peptic and duodenal ulcers, irritable bowel syndrome), as well as small cuts and wounds and mastitis, due to its antioxidant, anti-inflammatory, and antibacterial characteristics (Samec et al., 2011).

It has therapeutic value as well, since it has a cooling effect, promotes appetite, avoids constipation, speeds up digestion, and is especially beneficial to diabetic patients (Malik, 2008). Cabbage is high in vitamins A, C, K, B1, B2, B6, calcium, dietary fiber, and protein when eaten fresh in salads or boiled or cooked in stews or soups (Uddin et al., 2009). Cabbage is commonly consumed as a cooked or stir-fried vegetable, or as a raw element in salads such as coleslaw (a salad made of row cut and chopped cabbage) and mixed salads (Grubben and Denton, 2004). A 100gram serving of cabbage provides 1.8 grams of protein, 0.1 grams of fat, 4.6 grams of carbohydrate, 0.6 grams of mineral, 29 milligrams of calcium, 0.8 milligrams of iron, and 14.1 milligrams of sodium (Andersen, 2000). It's great in slaws, salads, and even cooked dishes (Andersen, 2000).

\subsection{Response of cabbage to natural fertilization}

Organic manuring can help to keep soil fertility and crop production in check. It is true that the use of inorganic fertilizers for crops has a negative impact on soil health due to lingering effects, but organic fertilizers do not have this issue. Furthermore, it improves soil productivity as well as crop quality and yield (Tindall, 2000). Chemical fertilizers are used by farmers as a quick source of nutrients; however they are not applied in a balanced quantity (BARC, 2005). Neither chemical fertilizers nor organic manure can help achieve long-term crop yield on their own. Due to deterioration in soil physical, chemical, and biological qualities, even with balanced use of just chemical fertilizer, high production levels could not be maintained over time (Khan et al., 2008).

Organic fertilizer boosts soil biological activity, nutrient mobilization, and soil structure, while also increasing soil water retention. The dynamics of nutrient availability differ between systems that use organic fertilizers as plant nutrient sources and those that use mineral fertilizers. Sustainable crop production with mineral and organic fertilizer integration has proven to be quite beneficial. Compost and other organic fertilizers are also helpful in the production of cabbage. They not only give nutrients to the soil, but they also improve the structure of the soil and the availability of nutrients to plants, hence increasing the efficacy of inorganic fertilizer applications. Sarker et al. (2002) found that a treatment combination of $60 \mathrm{~cm} \times 45 \mathrm{~cm}$ plant spacing with organic and inorganic fertilizers produced the best marketable yield of cabbage $\left(86.68 \mathrm{tha}^{-1}\right)$.

Anonymous (1991) found that applying $240 \mathrm{~kg} \mathrm{~N}, 60 \mathrm{~kg} \mathrm{P}$, and $120 \mathrm{~kg} \mathrm{~K} \mathrm{ha}^{-1}$, coupled with $5 \mathrm{t} \mathrm{ha}^{-1}$ cow manure, resulted in the highest cabbage head production $\left(75 \mathrm{tha}^{-1}\right)$. Farmyard manure slowly releases nutrients and activates soil microbial biomass (Ayuso et al., 1996; Belay et al., 2001). Organic manures can help agricultural systems last longer by improving nutrient recycling and soil physical characteristics (El-Shakweer, 1998). Several studies have shown the benefits of combining mineral and organic fertilizers in areas that had previously only received $\mathrm{N}, \mathrm{P}$, and $\mathrm{K}$ without any micronutrients or organic fertilizers for a few years (Chand et al., 2006; Kaur et al., 2005). The most effective strategy for ensuring long-term soil fertility and productivity is integrated nutrient management. However, in Ethiopia, this is not a common occurrence. Fertilizers are frequently applied according to general guidelines that apply to all soil types. Producing strong transplants for transplanted vegetables is essential for successful vegetable gardening. (Soundy et al., 2001a).

\subsection{Response of cabbage to inorganic fertilization}

Synthetic fertilizers created by industry are known as inorganic fertilizers (Utomo, et al., 2016). One of the keys to successfully increasing cabbage output is balanced fertilization. Nitrogen is one of the macronutrients that plants require in considerable amounts, and as a result, it is commonly deficient in plants. Nitrogen is taken up by plants in the form of $\mathrm{NO}^{-}$and $\mathrm{NH}^{+}$ions (Mengel and Kirkby, 2001). As a result, a nitrogen deficit could lead to stunted development and pale green leaves and stems (Mengel and Kirkby, 2001). In most plants, nitrogen has been shown to promote shoot growth at the expense of root development. Nitrogen application has been linked to increased plant height, stem diameter; leaf area, leaf number, total chlorophyll, and fresh and dry shoot mass (Zhang et al., 2009). In brassica vegetables, higher nitrogen levels have been proven to generate optimal yields. Higher nitrogen levels supported the growth of plants with larger leaf area, and it was more usefully utilized in head formation as a result (Mengel and Kirkby, 2001).

When the nitrogen application rate was increased, the relative core length increased, while the dry matter content of the heads decreased. This was linked to softer head tissue and lower physical resistance to stalk 
elongation with increasing nitrogen availability. The better the head quality, the shorter the proportional core length. As the nitrogen rate of the fertilizer is increased, the percent dry mass of the heads decreases, the number of burst heads increases, and the tip burn in the heads increases (Kumar and Rawat, 2002). Pre-plant treatments may result in losses or immobilization prior to plant absorption, reducing $\mathrm{N}$ use efficiency significantly (NUE). Split application is required to avoid nitrogen losses due to leaching and volatilization. Pre-plant applied nitrogen is prone to leaching and denitrification or immobilization before plant uptake, lowering $\mathrm{N}$ use efficiency (Subedi et al., 2007).

The amount of nitrogen and phosphorus required for the development of cabbage in Ethiopia is classified based on the soil fertility, according to ARARI (2005). For fertile soils, 150 kilogram DAP and $100 \mathrm{~kg}$ urea is recommended, whereas for non-fertile soils, $200 \mathrm{~kg}$ DAP and $100 \mathrm{~kg}$ urea is indicated. The first half of the urea and all of the DAP is applied at the time of planting, and the second half is applied 30 days later (ARARI, 2005).

\subsection{Economic important of combined application of organic and inorganic fertilizer}

Several field study reports have concluded that the only way to get high and long-term crop yields is to combine mineral fertilizer with organic manure (Satyanarayana et al, 2002). By converting inorganic nitrogen to organic forms, complementary application of organic and inorganic fertilizers improves nutrient synchronicity and lowers losses (Kramer et al., 2002). The combination of organic and synthetic nutrition sources not only provides needed nutrients, but also has a favorable interaction with chemical fertilizers, increasing their efficiency and reducing environmental risks. Soil additives are divided into two categories: organic and inorganic soil amendments. Plants and animals provide organic amendments, while. Inorganic amendments, on the other hand, can be mined or manufactured (Davis and Wilson, 2008).

Organic matter enhances soil aeration and water infiltration, as well as the capacity of soils to hold both water and nutrients. They aid in soil tilth maintenance by increasing the soil's ability to retain water (Sarka and Siegh 2002). As a result, according to Ball et al, (2005), organic fertilizers are also responsible for the development of soil aggregates, which are critical in sustaining soil fertility. Livestock dung contains all of the key nutrients $(\mathrm{N}, \mathrm{P}, \mathrm{K}, \mathrm{Ca}, \mathrm{Mg}, \mathrm{S}$, and others) required for plant growth, as well as micronutrients (Tremblay et al, 2011). Because decomposition of organic matter does not occur in a single year, manure application in one year will affect not just the crops cultivated that year, but its residual effects will continue to affect crops in subsequent years (Bayu et al., 2006). The use of organic materials as fertilizers supplies growth-regulating compounds while also improving the soil's physical, chemical, and microbiological qualities (Belay et al, 2001). Organic and inorganic fertilizers both give the nutrients that plants require to grow healthy and robust. Each, on the other hand, includes distinct substances and provides these ingredients in different ways.

Inorganic fertilizer provides fast nutrition while organic fertilizer works overtime to establish a healthy growing environment (Miller, 2008). Inorganic fertilizer, often known as synthetic fertilizer, is made from mineral or synthetic compounds and is generated artificially. Apart from soil mineral provision, organic fertilizers as a component of sustainable agriculture contribute to soil quality by enhancing the structure, chemistry, and biological level of soil in order to improve soil fertility and produce healthy crops with good yields. These contribute to the general health and form of agricultural soils. Another benefit is the progressive release of nutrients and the reuse of soil organic materials. This is one of the eco-supportive infrastructures promoted by Yusuf and Ukoje (2012) for sustainable rural development, and it is built largely on locally obtained materials with little or no reliance on external inputs. Inorganic fertilizers provide the advantage of knowing their nutrient content and releasing nutrients immediately because other materials do not need to be degraded. As a result, the time of nutrient intake may be accurately anticipated.

Because of its high cost, inorganic fertilizer has not proven beneficial in intensive agriculture, and it has been linked to lower crop yields, soil degradation, nutrient imbalance, and acidity (Kang and Juo, 1980; Obi and Ebo, 1995). For long-term cropping in the tropics, it is advised that organic and inorganic fertilizers be used in tandem (Ipimoroti et al., 2002). When both fertilizers were used, Fuchs et al. (1970) found that nutrients from mineral fertilizers improved crop establishment while nutrients from mineralization of organic manures increased yield. It has been discovered that adding manure to the soil increases its water holding capacity, implying that nutrients will be more readily available to crops in areas where manure has been applied (Costa et al., 1991). Murwira and Kirchman (1993) discovered that combining manure and inorganic fertilizer could improve nutrient usage efficiency.

Experiments conducted in India revealed that treatment combinations with organic and inorganic fertilizers resulted in significantly higher cabbage head production $\left(42.42 \mathrm{t} \mathrm{ha}^{-1}\right)$ than the control with the addition of 150 $\mathrm{kg} \mathrm{N}$ ha ${ }^{-1}$ fertilizer in combination with $10 \mathrm{t} \mathrm{ha}^{-1}$ FYM (38.10 $\left.\mathrm{t} \mathrm{ha}^{-1}\right)$. Plant height, root length, number of loose leaves and heading leaves, leaf length and width, thickness and diameter of head, and yield were all best in another field experiment with $240 \mathrm{~kg} \mathrm{~N}, 45 \mathrm{~kg} \mathrm{P}, 180 \mathrm{~kg} \mathrm{~K}$, and $45 \mathrm{~kg} \mathrm{~S} \mathrm{ha}^{-1}$. An application of $240 \mathrm{~kg} \mathrm{~N}, 45 \mathrm{~kg}$ $\mathrm{P} \mathrm{ha}^{-1}$ resulted in the highest marketable yield (87.09 t/ha) (Brady, 2003). According to Lesic et al. (2004), cabbage has high requirements for all nutrients, notably nitrogen, ranging from 130 to $310 \mathrm{~kg} \mathrm{~N} \mathrm{ha}^{-1}$ for high 
yields.

\section{SUMMERY AND CONCLUSION}

Cabbage is an important vegetable crop in Ethiopia, although typical yields are low due to a variety of limiting factors, the most significant of which being the use of nitrogen fertilizer at an inadequate rate. However, in recent years, the use of both organic and inorganic fertilizers on cabbage has been a key study focus. Farmers and other value chain participants now have access to some of the study findings along the way, particularly on cabbage. Cabbage is one of Ethiopia's most popular and commonly cultivated vegetables.

It is a perishable food, and local production is frequently vulnerable to insufficient organic and inorganic fertilizer treatment. Nonetheless, the effect of combining organic and inorganic fertilizers on cabbage production is given top emphasis, and the best combination for optimizing cabbage yield has yet to be determined. The combination of organic and synthetic nutrient sources not only provides critical nutrients for cabbage, but also has a good interaction with chemical fertilizers, increasing their efficiency and reducing environmental risks.

The use of organic materials as fertilizers supplies growth-regulating compounds while also improving the soil's physical, chemical, and microbiological qualities. Because decomposition of organic matter takes more than a year, manure application in one year will affect not just the cabbage cultivated that year, but its leftover effects will continue to influence cabbage in subsequent years. Inorganic fertilizers provide the advantage of knowing their nutrient content and releasing nutrients immediately because other materials do not need to be degraded. As a result, the time of nutrient intake may be accurately anticipated. Therefore an intervention that leads to increasing the cabbage yield through enhancing the soil fertility by combined application of fertilizer is paramount important.

\section{RECOMANDATION}

So, from these review the following aspect should be considered;

$\checkmark$ In order to draw a general recommendation further research should be done on combined application of organic and in organic fertilizer on cabbage.

$\checkmark \quad$ There is a need for testing the fertility and $\mathrm{P}^{\mathrm{H}}$ of the soil in the study area in addition to combined application on cabbage production.

$\checkmark \quad$ The researcher should be under consideration integrated management of pre harvest and post-harvest practices in the area of the field for best quality production of cabbage.

$\checkmark$ There is also a need for carry out research not only on the combined application of cabbage but also post-harvest loss of cabbage.

$\checkmark$ Finally, for the best quality product, the research is required through incorporation combined application of fertilizer as well as pre-harvesting post-harvest practices taking other factors under consideration in the specific area.

\section{REFERENCES}

Alistribigge and Androsen E., 2013.Important of vegetables in economical and rotational crop in the vegetable growing areas. Thohanwiley and Jons, form to Canada.

Amhara Regional Agricultural Research Institute (ARARI). 2005. Horticultural crops production training manual (in Amharic) for Developmental Agents volume 3. Amhara agricultural research institute. July, 2005 Bahir Dar, Ethiopia

Andersen C., 2000. Cabbage home gardening series. University of Arkansas. Website: http://www.uaex.edu/Other_Areas/publications/HTML/FSA-6006.asp

Anonymous., 2011. Health Care. Accessed on http://www.healthcareclinic.org/vegetables

Asare, Ayeh and Heng., 2010. Yield, water and nitrogen use by drip irrigation, cabbage growth under different level of applied water Biotechnology and nuclear Agricultural institute GAEL, Austria. pp. 191-14.

Ashworth., 2002. Seed to Seed: Seed Saving and Growing Techniques for Vegetable Gardeners. New York: Seed Savers Exchange In, Pp: 54-68.

Ayuso M. A; Pascal J. A; Garcia C. and Hernandez T. 1996. Evaluation of urban wastes for urban agricultural use. Soil science and plant nutrition 142:105-111.

Ball B., Bingham I., Rees R., Watson C., and Litterick A., 2005. The role of crop rotation in determining soil structure and crop growth conditions: Canadian J. Soil. Sci. 85 (50): 557-578

Bangladesh Agricultural Research Council (BARC). 2005. Fertilizer Recommendation Guide 2005, BARC, Soils Pub., No. 45, Bangladesh Agri. Res. Council, Farm gate, Dhaka.

Bayu W., Rethman N., Hammes P. and Alamu G., 2006. Effects of farmyard manure and Inorganic Fertilizers on sorghum Growth, Yield and Nitrogen use in a semi- arid area of Ethiopia. J. Plant Nutri. 29(2):391-407.

Belay A., Classens A., Wehner F. and Beer J., 2001. Influence of residual manure on selected nutrient 
elements and microbial composition of soil under long-term crop rotation. South African J. of Plant and Soil, 18:16.

Bhuiyan, N.I. 2010.Application of integrated plant nutrition system (IPNS) in Agriculture- Bangladesh Experiences. Workshop on integrated plant nutrition system development and rural poverty alleviation, 1820 September 2010. Bangkok, Thailand.

Bok I, Madisa M, Machacha D, Moamogwe M, More K. (Revised). 2006. Manual for Vegetable Production in Botswana. Department of Agriculture Research, Gaborone, Botswana. Pp57.

Brady N. and Weil R., 2002. The nature and properties of soils. Thirteenth Ed Prentice Hall Publishing, New Jersey. pp. 900-960.

Bulluck, L.R., Brosius, M., Evanylo, G.K. and Ristaino J.B. 2002. Organic and Synthetic Fertility Amendments Influence Soil Microbial, Physical and Chemical Properties on Organic and Conventional Farms. Applied Soil Ecology, 19:147-160.

Bumb, B.L. and Baanate, C.A. 1996. The role of fertilizer in sustaining food security and Protecting the Environment. International Food Policy Research Institute, 5(3):36-38.

Chadha B. 2006. Hand Book of Horticulture. Fifth Reprint Indian Council of Agricultural Research New Delhi published by kuldeep Sharma, New Delhi (Infdia).

Chadha B., 2006. Hand Book of Horticulture. Fifth Reprint Indian Council of Agricultural Research New Delhi published by kuldeep Sharma, New Delhi (Infdia).

Chand, S., Anwar M. and Patra, D., 2006. Influence of long-term application of organic and inorganic fertilizer to build up soil fertility and nutrient uptake in mint-mustard cropping sequence. Communications in Soil Science and Plant Analysis, 37: 63-76.

Costa F. C. Hernadez G. C. and Polo A. (1991). Residuos organicos urbanicos in manejoy utilizacion CSIC Munica $\mathrm{p} 181$.

Davis J. and Wilson C., 2008. Choosing a soil amendment. Colorado State University, Extension bulletin. No.7.235.

El-Shakweer M. H. A, El-Sayad E. A. and Ewees M. S. 1998. Soil and Plant analysis as a guide for interpretation of the improvement efficiency of organic conditioners added to different soils in Egypt. Communication in soil science and plant analysis 29:20672088.

FAO (Food and Agriculture Organization), 2008. Water development and management. HCMP.

FAO (Food and Agriculture Organization), 2012. Food and Agricultural organization statistics. FAO, Rome.

Food and Agriculture Organization of the United Nations (FAO). 2014. The Food and Agriculture Organization database (FAOSTAT). http://faostat3.fao.org/home/E

Fuchs W.; Rauch, K and Wiche H. J. 1970. Effect of organic fertilizer and organo mineral fertilizing on development and yield of cereals. Abrecht- Thaer arch 14: 359-366.

Grubben G., Denton O., Messiaen C. and Schippers R., 2004. Plant resource of Tropical Africa and vegetables. PROTA foundation, Wageningen, Netherlands / Backlmys Publishers, Leiden, Netherlands / CTA Wageningen, Netherlands. $668 \mathrm{pp}$.

Illeert S., 2005. Mini- Gemuse. 12,66-68. Improved Production Technologies in Vegetable Crops.IIVR Training Manual No. 59. ICAR-Indian Institute of Vegetable Research, Varanasi, India, Pp 268.

Indian Horticulture Database (IHD). 2014. Indian Horticulture Database 2014. National Horticulture Board, Ministry of Agriculture, Government of India 85, Institutional Area, Sector-18, Gurgaon-122 015 INDIA

Ipimoroti R. R.; Daniel M. A. and Obatolu C. R. 2002. Effect of organic mineral fertilizer on tea growth at Kusuku Mabila Plateau Nigeria. Moor Journal of Agric.Research 3: 180183.

Kang B. T. and Juo A. S. R. 1980. Management of low activity clay soils in tropical Africa for food crops production pp129-133 In: Terry ER, KA Oduro and S Caveness (eds.) Tropical Roots crops. Research strategies for the 1980s. Ottawa, Ontario IDRC.

Kaur K., Kapoor K. and Gupta A., 2005. Impact of organic manures with and without mineral fertilizers on soil chemical and biological properties under tropical conditions. Journal Plant Nutrition and Soil Science, 168: 117-122.

Kaur, K., Kapoor, K.K. and Gupta, A.P. 2005. Impact of organic manures with and without mineral fertilizers on soil chemical and biological properties under tropical conditions. Journal Plant Nutrition and Soil Science, 168: $117-122$

Khan, Shil N. and Noor S., 2008. Integrated nutrient management for sustainable yield of major vegetable crops in Bangladesh. Bangladesh J. Agric. Environ. 4, 81-94.

Kibar B., Karaağaço and Hayati K., 2014. Correlation and Path Coefficient Analysis of Yield and Yield Components in Cabbage (Brassica Oleracea Var. Capitata L.) Acta Sci. Pol. 13(6):87-97.

Kramer A., Doane T., Horwath W., Kessel C., 2002.Combining fertilizer and inorganic inputs to synchronize $\mathrm{N}$ supply in alternative cropping systems in California. J. Agric. Econ. Environ.91:233 -243 . 
Kumar and Rawat T., 2002. Effect of nitrogen and spacing on the quality and yield of cabbage (Brassica oleracea L. var. capitata). Agric. Sci. Digest 22(2), 9092.

Lesic, R., Borosic, J., Buturac, I., Herak-Custic, M., Poljak, M. and Romic, D. 2004. Povrcarstvo. Zrinskid Cakovec. Dhaka, 65-93.

Malik N., 2009. Horticulture. Biotech Books Delhi, India- 110035 Pp 515

Meena, Rubee L. and Sharma S., 2010. Determining yield components in cabbage (Brassica oleracea var. capitata L.) through correlation and path analysis. Int. J. Sci. Nat. 1:27-30.

Mengel and Kirkby E., 2001. Principles of plant nutrition. 5th Ed.: International Potash Institute, Bern, Switzerland.

Miller R., 2008. Inorganic fertilizer verses organic fertilizer.

MoA (Ministry of Agriculture). 2011. Animal and Plant Health Regulatory Directorate. Crop Variety Register: ISSUE No 14. Pp:182-188.

Moamogwe M. 2005. Adaptation Trial of Introduced Cabbage Cultivars. ARP Training

Molla Tefera. 2009. Determination of the Levels of Essential and Non - Essential Metals in Commercially Available Ethiopian Red Pepper (capsicum annuum). MSc Thesis, Addis Ababa University, Addis Ababa, Ethiopia.

Murwira H. K. and Kirchman A. K. 1993. Carbon and nitrogen mineralization of cattle manures subjected to different treatment in Zimbabwean and Swedish soils:In K Mulongoy and K.R Merckr (editors)Soil organic matter dynamics and sustainability of tropical agriculture pp189-198.

National Department of Agriculture, 2003. Abstract of Agricultural Statistics. South Africa.

Nicolas D., Francis M. and Guido P., 2012. Food Production and Consumption Trends in Sub-Saharan Africa: Prospects for the Transformation of the Agricultural Sector. African Center for Economic Transformation. Guido Porto Universidad Nacional de La Plata.

Obi M. E and Ebo P. O. 1995.The effect of different management practices $\mathrm{n}$ the soil physical properties and maize production in severely degraded soil in /Southern Nigeria. Biological resource technology 51: 117123.

Ogbodo and Utobo E., 2009. Evaluation of the adaptability of cabbage (Brassica oleracea L. varcapitata) to the agro- ecology of Ebonyi State,South-eastern Nigeria. Int. J. Sustainab. Agric. 1:41-48.

Palm, C.A., Myers, P.J.K.R and Nandwa, S.M. 1997. Combined use of organic and inorganic nutrient sources for soil fertility maintenance and replenishment. In: Buresh et al.(eds.). Replenishing soil fertility in Africa. American Society of Agronomy, 51:193 - 217.

Romain H., 2001. Crop Production in Tropical Africa. Published by Ministry of Foreign

Samec D., Piljac-Zegarac J. and Bogovi M., 2011. Antioxidant potency of white (Brassica oleracea L. var. capitata) and Chinese (Brassica rapa L. var. pekinensis (Lour.)) cabbage: The influence of development stage, cultivar choice and seed selection. Sci Hort, 128, 78-83.

Sarka A., and Siegh R., 2002. Importance of Long Term Fertilizers Use for Sustainable Agriculture in Jharkhand. The Second International Congress on Balancing Food and Environmental Security-A Continue Challenge, New Delhi. India, 26-30 November 2002. Fertilizer News 2002; 47:107-117.

Sarker and Baset M., 2002. Effect of plant spacing and Sources of Nutrients on theGrowth and Yield of Cabbage. Pak. J. Biol. Sci. 5(6):636-639.

Satynarayana V., Vera P., Murphy V., and Boots K., 2002. Influence of Integrated use of farmyard manure and inorganic fertilizer on yield and yield components of irrigated lowland rice. J. Plant Nutri. 25 (10): 281-2090

Schlegel R., 2010. Dictionary of plant breeding (second edition). CRC Press Taylor and Francis Group Boca Raton London New York Pp571

Semuli K., 2005. Nitrogen requirements for cabbage transplant and crop response of spacing and nitrogen top dressing. Department of soil production and soil science, Faculty of natural and agricultural sciences, University of Pretoria.

Singh B., Sharma S. and Singh B., 2009. Heterosis for mineral elements in single crosshybrids of cabbage (Brassica oleracea var. capitata L). Scientia Horticulturae 122(1): 32-6.

Singh N., Shubhadeep R., Pradip K., Chaurasia S., Gupta S. and Singh B., 2015.

Sorensen, J.N. 2003. Improved N efficiency in vegetable production by fertilizer placement and irrigation. Acta Horticulture, 428:131-140.

Soundy and Stoffella P., 2001a. Nutrient requirements for lettuce transplants using floatation irrigation system. I. Phosphorus. HortScience. 36 (6), 1066-1070.

Subedi, K.D., B.L. Ma and A.G. Xue. 2007. Planting date and nitrogen effects on grain yield and protein content of spring wheat. Crop Sci., 47: 36-44.

The Fertilizer Society of South Africa, 2000. Fertilizer handbook. Beria Printers. Lynwood Ridge, South Africa.

Tindall M., 2000. Mineral and organic fertilizing in cabbage. Residual effect for commercial cultivation 
on yield and quality performance with organic farming. Hort. Bras. 6, 15-20.

Tiwari and Mal P., 2003. Effect of drip irrigation on yield of cabbage (Brassica oleracea L. var. capitata) under mulch and non-mulch conditions. Agric. Water Manag. 58,19-28.

Tremblay N., Bouroubi M., Vigneault P., and Belec C., 2011. Guidelines for in-season nitrogen application for maize (Zea mays L.) based on soil and terrain properties. Field Crops Res.122:273283. doi: 10.1016/j. fcr.2011.04.008

Uddin M., Islam M. and Naher M., 2009. Basic Agriculture, Part I. 74/4, Upashahar, Rajshahi. 379 p.

Utomo M., Sabrina T., Lumbanraja J. and Wawan., 2016. “Ilmu Tanah: Dasar-dasar dan Pengelolaan”. 367 pp. Prenada Media.

Wakene, N., Kafyalew, N., Friesen, D.K., Ransom, J. and Yadessa, A. 2001. Determination of Optimum Farmyard Manure and NP Fertilizers for Maize on Farmer's Field. 7th Eastern South Africa Regional Maize Conference. Pp:387-393.

Yano M, Ito H, Hayami A. and Obama S. 1999. Effect of cultural practices on the quality of vegetables. Sugar contents of cabbage and carrot. Bulletin of National Institution of Vegetable and Tea Science, Pp: 53-67.

Yusuf O. and Ukoje J., 2012. "The Imperative of "Eco- supportive" Infrastructure for Sustainable rural livelihood in a changing Climate' in Iliya, M.A,Abdulrahim,M.A, Dankani I. and Opponkumi, A (eds) Climate Change and Sustainable Development. Proceedings of the $52^{\text {nd }}$ Annual conference of the Association of, (Nigerian Geographers ANG) held at Usman Danfodiyo University, Sokoto.

Zhang F. and ZhaoY., 2009. A new mini type chinses cabbage F1 Hybrid-Jing qiuwacai for autumn cultivation. China Veget., 24, 72-73. 